\title{
KINERJA PEMERINTAH DESA DALAM PENGELOLAAN ALOKASI DANA DESA DI DESA CIBUNUT KECAMATAN ARGAPURA KABUPATEN MAJALENGKA PROVINSI JAWA BARAT
}

\author{
Oleh \\ Ahmad Zulfikar \\ Mahasiswa Program Pascasarjana Magister Terapan Ilmu Pemerintahan IPDN \\ ahmadzulfikar88@gmail.com
}

\begin{abstract}

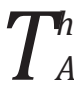
This activity puts the Government Performance in Village Fund Management in Cibunut Village Argapura District, Majalengka Regency, West Java Province. This research is motivated by the interest of the writer on factors influencing the performance of Village Government in the Management of Village Fund Allocation. From the results of interviews and initial observations the inventor finds the problem that the human resources apparatus cibunut village managing keuangan still low tingkat education. the minimal allocation of cibunut village funds for the construction of village infrastructure and the lack of community involvement in planning the use of village fund allocations. The research method used is descriptive research method, with qualitative approach. Data obtained through data collection techniques: interviews and documentation.

The results of this study indicate that the Performance of Village Governments in the Management of Village Fund Allocation in Cibunut Village Argapura District Majalengka District West Java Province has not been effectively implemented. This can be seen from the number of families in the village of Cibunut which increased the funds disbursed Government Majalengka increased. This is as a result of the Village Fund Allocation that can not be generalized to all villages in Majalengka District.

Theoretical suggestions need to be studied in depth about the performance of village government in managing the Village Fund Allocation. Furthermore, the practical suggestion of Village Fund Allocation Management can be run effectively if the Local Government of Majalengka Regency as soon as possible to change the Regulation of Majalengka Regent No. 4 of 2013 on Guidelines for Implementation of Majalengka Village Fund Allocation. Cibunut Village Government should prioritize program activities tailored to the real needs and interests of the community through bottom up development planning, Cibunut Village Government should implement various alternative strategies in the management of Village Fund Allocation by mutual coordination between management organizations and other cross sectors..
\end{abstract}

Keywords: management performance and allocation of village funds.

\section{Abstrak}

$\mathrm{P}$ enelitian ini berjudul Kinerja Pemerintah Desa dalam Pengelolaan Alokasi Dana Desa di Desa Cibunut Kecamatan Argapura Kabupaten Majalengka Provinsi Jawa Barat. Penelitian ini dilatarbelakangi karena ketertarikan penulis meneliti terhadap permasalahan yang timbul mengenai Kinerja Pemerintah Desa dalam Pengelolaan Alokasi Dana Desa. Dari hasil 
wawancara dan observasi awal, penulis menemukan masalah yang di antaranya sumber daya manusia aparatur desa Cibunut yang mengelola keuangan masih rendah tingkat pendidikannya, Minimnya Alokasi Dana Desa Cibunut untuk pembangunan infrastruktur desa serta kurang dilibatkannya masyarakat dalam perencanaan penggunaan Alokasi Dana Desa.

Metode penelitian yang digunakan dalam penyusunan tesis ini adalah metode penelitian deskriptif, dengan pendekatan kualitatif. Data diperoleh melalui teknik pengumpulan data: observasi, wawancara dan dokumentasi.

Hasil penelitian ini menunjukkan bahwa Kinerja Pemerintah Desa dalam Pengelolaan Alokasi Dana Desa di Desa Cibunut Kecamatan Argapura Kabupaten Majalengka Provinsi Jawa Barat belum efektif dilaksanakan. Hal ini dapat dilihat dari jumlah kepala keluarga miskin di Desa Cibunut semakin meningkat padahal dana yang dikucurkan Pemerintah Kabupaten Majalengka cenderung meningkat. Hal ini dikarenakan hasil pengelolaan Alokasi Dana Desa tidak sepenuhnya dinikmati oleh masyarakat miskin dan pembagian besaran alokasi dana desa yang masih disamaratakan untuk seluruh desa di Kabupaten Majalengka.

Saran teoritis perlu dikaji secara mendalam mengenai kinerja pemerintah desa dalam pengelolaan Alokasi Dana Desa. Selanjutnya saran praktis sebaiknya Pengelolaan Alokasi Dana Desa dapat berjalan secara efektif apabila Pemerintah Daerah Kabupaten Majalengka sesegera mungkin mengubah Peraturan Bupati Majalengka Nomor 4 Tahun 2013 tentang Pedoman Pelaksanaan Alokasi Dana Desa Kabupaten Majalengka. Pemerintah Desa Cibunut sebaiknya memprioritaskan program kegiatan yang disesuaikan dengan kebutuhan riil dan kepentingan masyarakat melalui perencanaan pembangunan yang bersifat bottom up, Pemerintah Desa Cibunut sebaiknya melaksanakan berbagai alternatif strategi dalam pengelolaan Alokasi Dana Desa dengan saling berkoordinasi antar- organisasi pengelola dan lintas sektor lainnya.

Kata kunci: kinerja pengelolaan dan alokasi dana desa

\section{PENDAHULUAN}

$\mathrm{D}$ esa Cibunut bagian dari 14 desa yang ada di Kecamatan Argapura Kabupaten Majalengka dan mempunyai 4 dusun dengan jumlah 8 RW dan 16 RT, dengan rincian sebagai berikut.

Tabel 1 Data Jumlah Penduduk Desa Cibunut Tahun 2016

\begin{tabular}{llcc}
\hline No & Dusun & $\begin{array}{c}\text { Jumlah } \\
\text { RW }\end{array}$ & $\begin{array}{c}\text { Jumlah } \\
\text { RT }\end{array}$ \\
\hline 1 & Cukangsari & 2 & 4 \\
\hline 2 & Desa & 2 & 4 \\
\hline 3 & Girang Kulon & 2 & 4 \\
\hline 4 & Girang Wetan & 2 & 4 \\
\hline JUMLAH & 8 & 16 \\
\hline
\end{tabular}

Sumber: Sekretariat Desa Cibunut 2016

Pemerintah desa merupakan unit terdepan dan berhadapan langsung dalam pelayanan pemerintahan dan pemberdayaan masyarakat, serta menjadi tonggak utama untuk keberhasilan semua program pemerintah. Sebagai unit penyelenggaraan pemerintahan terbawah, maka profesionalisme perangkat desa mutlak dibutuhkan, mengingat tugas dan fungsi desa yang harus diemban oleh aparatur desa cukup kompleks, antara lain adalah mengatur pemerintahan, pembangunan dan masyarakat agar tercipta "keteraturan dan ketertiban", pelayanan: mengurus kepentingan dan kebutuhan masyarakat guna mendukung kesejahteraan serta meningkatkan kekuatan dan potensi masyarakat agar masyarakat bisa mandiri dan sejahtera. Untuk aparatur pemerintah Desa Cibunut sendiri berdasarkan pendidikan yang disandangnya bisa dilihat pada tabel berikut ini:

Tabel 2 Data Aparat Desa Berdasarkan Pendidikan Desa Cibunut Tahun 2017

\begin{tabular}{llll}
\hline No & Jabatan & Nama & $\begin{array}{l}\text { Pend- } \\
\text { dikan }\end{array}$ \\
\hline 1 & Kepala Desa & Indra, S.Pd & S1 \\
\hline
\end{tabular}




\begin{tabular}{|c|c|c|c|}
\hline 2 & $\begin{array}{l}\text { Sekretaris } \\
\text { Desa }\end{array}$ & $\begin{array}{l}\text { Haris Aziz } \\
\text { Susilo, S.Pd }\end{array}$ & S1 \\
\hline 3 & $\begin{array}{l}\text { Kasi } \\
\text { Pemerintahan }\end{array}$ & Ihin Salohin & SMA \\
\hline 4 & Kasi Ekbang & Agus Lili & SMA \\
\hline 5 & Kasi Kesra & $\begin{array}{l}\text { Pipih Aripin, } \\
\text { S.Pd }\end{array}$ & S1 \\
\hline 6 & Kaur Umum & $\begin{array}{l}\text { Sidik } \\
\text { Habudin }\end{array}$ & SMP \\
\hline 7 & $\begin{array}{l}\text { Kaur } \\
\text { Keuangan }\end{array}$ & $\begin{array}{l}\text { Cicih } \\
\text { Yunarsih }\end{array}$ & SMA \\
\hline 8 & Kaur Aset & Yayan, S.Pd & S1 \\
\hline 9 & $\begin{array}{l}\text { Kepala Dusun } \\
\text { Cukangsari }\end{array}$ & Rudiyanto & SMK \\
\hline 10 & $\begin{array}{l}\text { Kepala Dusun } \\
\text { Desa }\end{array}$ & $\begin{array}{l}\text { Anjun } \\
\text { Hidayat }\end{array}$ & SMP \\
\hline 11 & $\begin{array}{l}\text { Kepala Dusun } \\
\text { Girang Kulon }\end{array}$ & $\begin{array}{l}\text { Egi Setiyadi } \\
\text { Nugraha, } \\
\text { S.Pd }\end{array}$ & S1 \\
\hline 12 & $\begin{array}{l}\text { Kepala Dusun } \\
\text { Girang Wetan }\end{array}$ & $\begin{array}{l}\text { Acip } \\
\text { Nursucipto } \\
\text { Herawanto } \\
\text { S.T }\end{array}$ & $\mathrm{S} 1$ \\
\hline
\end{tabular}

Sumber: Sekretariat Desa Cibunut 2017

Dari tabel di atas kita bisa melihat bahwa pendidikan aparatur Desa Cibunut khususnya kaur keuangan belum cukup baik. Hal ini bisa dilihat dari latar pendidikannya yang hanya lulusan SMA. Kemudian dalam hal anggaran pendapatan dan belanja desa, pemerintah Desa Cibunut mempunyai anggaran yang cukup besar. Hal ini memberikan peluang kepada masyarakat untuk bisa sejahtera, membangun perekonomian yang menguntungkan kebutuhan masyarakat Desa Cibunut. Anggaran merupakan faktor pendukung yang sangat penting bagi berjalannya pemerintahan desa oleh karena itu pengelolaan keuangan desa harus benar dilakukan oleh orang yang berkompeten.

Anggaran desa harus benar-benar dialokasikan dalam rangka menggali potensi dan sumber daya yang ada di Desa dan dapat diefektifkan untuk mendukung perwujudan pembangunan desa yang merata. Di mana pembangunan desa diupayakan untuk dapat meningkatkan kualitas hidup dan kesejahteraan masyarakat desa. Untuk anggaran pendapatan dan belanja desa Cibunut pada tahun 2016 mencapai Rp 1.041.851.100,00. Sebagaimana kita bisa lihat pada tabel di bawah ini:

Tabel 3 Anggaran Pendapatan dan Belanja Desa Pemerintah Desa Cibunut Tahun 2017

\begin{tabular}{lr}
\hline \multicolumn{1}{c}{ Uraian } & Anggaran (Rp.) \\
\hline Pendapatan & \\
Pendapatan Asli Desa & $49.500 .000,00$ \\
Hasil Usaha (Bengkok & $39.500 .000,00$ \\
Desa) & \\
Swadaya, Partisipasi dan & $10.000 .000,00$ \\
Gotong Royong & \\
Lain-lain Pendapatan & \\
Asli Desa yang sah & \\
Pendapatan Transfer & $992.351 .100,00$ \\
Dana Desa & $615.206 .300,00$ \\
Bagian dari hasil pajak & \\
\&retribusi daerah & \\
kabupaten/kota & \\
Alokasi Dana Desa & \\
Bantuan Keuangan & \\
Bantuan Provinsi & \\
Bantuan Kabupaten/ & \\
Kota & \\
Pendapatan Lain lain & $15.000 .000,00$ \\
Hibah dan Sumbangan & \\
dari pihak ke-3 yang & \\
tidak mengikat & \\
Lain-lain Pendapatan & \\
Desa yang sah & \\
Jumlah Pendapatan & \\
\hline
\end{tabular}

Sumber: Peraturan Desa Nomor 2 Tahun 2016

Dari tabel di atas kita melihat begitu cukup besar anggaran pendapatan dan belanja desa Cibunut. Anggaran besar tersebut harus benar-benar dapat dikelola dengan baik. Besaran alokasi dana desa di Desa Cibunut pada tahun 2016 tersebut mencapai Rp.362.144.800,00 dengan rincian penggunaan alokasi sebagai berikut. 
Tabel 4 Penggunaan Alokasi Dana Desa Cibunut tahun 2016

\begin{tabular}{lr}
\hline \multicolumn{1}{c}{ Uraian } & Anggaran (Rp) \\
\hline Penghasilan Tetap dan & 260880000 \\
Tunjangan & 46399800 \\
Operasional Perkantoran & 1200000 \\
Operasional BPD & 6720000 \\
Operasional RT/RW & 2925000 \\
Operasional LPM & 8112000 \\
Operasional PKK & 1200000 \\
Operasional Linmas & 2490000 \\
Operasional Karang Taruna & 1000000 \\
Penetapan dan penegasan & 900000 \\
batas desa & 1500000 \\
Pendataan Profil Desa & \\
Penyelenggaraan Musyawah & 16770000 \\
Desa & \\
Bronjong 3 Dusun Cibunut & 12048000 \\
Kulon & \\
Pembangunan TPT Blok & 362144800 \\
Cukangsari & \\
\hline Jumlah & \\
\hline
\end{tabular}

Sumber: Kantor Desa Cibunut 2016

Dari data di atas penggunaan Alokasi Dana Desa Cibunut lebih banyak digunakan untuk membayar aparatur Desa Cibunut dibandingkan belanja pembangunan infrastruktur desa. Selain itu juga berdasarkan hasil wawancara awal dengan ketua Badan Permusyawaratan Desa Cibunut, mengungkapkan bahwa: dalam pengelolaan Alokasi Dana Desa pihak Badan Permusyawaratan Desa Cibunut tidak dilibatkan dalam perencanaan pengalokasian Alokasi Dana Desa. Saya hanya diberi tahu oleh pemerintah desa Cibunut ketika pengalokasian Alokasi Dana Desa tersebut sudah rampung tersusun tinggal ditanda tangan saja sebagai persetujuan dari Badan Permusyawaratan Desa Cibunut.

Tidak dilibatkannya stakeholders dalam perencanaan penggunaan Alokasi Dana Desa di Desa Cibunut menjadikan penggunaan Alokasi Dana Desa dilakukan secara otoriter oleh pemerintah Desa
Cibunut tanpa menerima masukan aspirasi dari para stakeholders masyarakat. Sebagaimana yang diungkapkan oleh masyarakat Desa Cibunut pada saat wawancara awal mengungkapkan bahwa, "Kami sebagai masyarakat kurang dilibatkan dalam proses perencanaan penggunaan Alokasi Dana Desa, sehingga kami tidak mengetahui penggunaan Alokasi Dana Desa semuanya, kami hanya mengetahui bentuk fisik yang dibangun oleh pemerintah Desa Cibunut".

\section{METODE PENELITIAN}

Metode kualitatif menurut Sugiyono (2005: 4) suatu metode penelitian yang digunakan untuk meneliti pada kondisi objek yang dialami (sebagai lawannya adalah eksperimen), di mana peneliti adalah instrument kunci. Selanjutnya Creswell (2010: 20) mengemukakan bahwa:

Penelitian kualitatif adalah suatu proses penelitian untuk memahami masalahmasalah manusia atau sosial dengan menciptakan gambaran menyeluruh dan kompleks yang disajikan dengan kata-kata, melaporkan pandangan terinci yang diperoleh dari para sumber informasi, serta dilakukan dalam latar (setting) yang alamiah.

Silalahi mengemukakan juga bahwa: metode (atau pendekatan) kualitatif menawarkan beberapa tradisi dalam metode pengumpulan data, analisis, dan penulisan laporan, atau rancangan menyeluruh yang mencakup seluruh tahap dalam proses penelitian. Benister dkk yang dikutip oleh Alsa (2004: 30) mengemukakan bahwa: Penelitian kualitatif dapat didefinisikan sebagai satu cara sederhana, sangat longgar, yaitu suatu penelitian interpretatif terhadap suatu masalah yang dibuat mengenai masalah itu. Lebih lanjut Kirk dan Miller yang dikutip oleh Moleong (2002: 2) mengemukakan bahwa: 
Penelitian kualitatif adalah tradisi tertentu dalam ilmu pengetahuan sosial yang secara fundamental bergantung pada pengamatan pada manusia dalam kawasannya sendiri dan berhubungan dengan orang-orang tersebut dalam bahasannya dan dalam peristilahannya.

Penelitian kualitatif tersebut dipilih dengan pertimbangan bahwa dengan melalui penelitian kualitatif diharapkan akan mampu mengkaji masalah penelitian secara mendalam, sehingga dapat memperoleh dan mempermudah penjelasan yang bermakna tentang Kinerja Pemerintah Desa dalam Pengelolaan Alokasi Dana Desa di Desa Cibunut Kecamatan Argapura Kabupaten Majalengka Provinsi Jawa Barat. Teknik pengumpulan data yang digunakan oleh peneliti dalam penelitian ini yaitu:

1. Wawancara

$\begin{array}{lcr}\text { Dengan wawancara maka } & \\ \text { peneliti dapat mengetahui dan }\end{array}$ mendengarkan pendapat dan ide-ide dari informan. Dalam penelitian ini peneliti menggunakan wawancara semiterstruktur yang dilakukan secara mendalam. Wawancara dilakukan dengan Kasi Pengembangan Ekonomi Dinas Pemberdayaan Masyarakat dan Desa Kabupaten Majalengka Camat Argapura, Kepala Desa Cibunut, Ketua Badan Permusyawaratan Desa Cibunut, Kepala Dusun (Cukangsari, Desa, Girang Kulon dan Girang Wetan) Tokoh (agama/LPM, pemuda, perempuan dan pendidikan).

2. Observasi/pengamatan

Pengamatan yang dilakukan oleh peneliti adalah untuk mendapat gambaran secara menyeluruh tentang Kinerja Pemerintah Desa dalam Pengelolaan Alokasi Dana Desa di Desa Cibunut Kecamatan Argapura Kabupaten Majalengka Provinsi Jawa Barat. Hal ini dilakukan untuk lebih memperoleh data yang akurat.

\section{Dokumentasi}

Dokumentasi merupakan cara pengumpulan data yang dilakukan dengan kategorisasi dan klasifikasi bahan-bahan tertulis yang berhubungan dengan penelitian, baik itu datadata sumber dokumen maupun buku-buku, koran, majalah dan lainlainnya; termasuk berbagai peraturan perundang-undangan yang berkaitan dengan Kinerja Pemerintah Desa dalam Pengelolaan Alokasi Dana Desa di Desa Cibunut Kecamatan Argapura Kabupaten Majalengka Provinsi Jawa Barat. Teknik ini merupakan pelengkap dari penggunaan metode wawancara dan observasi dalam penelitian kualitatif.

Lokasi penelitian dilakukan di Desa Cibunut Kecamatan Argapura Kabupaten Majalengka Provinsi Jawa Barat.

\section{LANDASAN TEORETIS}

Dalam konteks penelitian ini konsep yang digunakan untuk mengukur kinerja adalah konsep Kinerja menurut Lenvine dalam Dwiyanto (2008: 51), mengusulkan tiga konsep yang bisa dipergunakan untuk mengukur kinerja birokrasi publik/ organisasi non bisnis yaitu:

1. Responsivitas

Responsivitas di sini adalah kemampuan organisasi untuk mengenali kebutuhan masyarakat, menyusun agenda dan prioritas pelayanan, dan mengembangkan program-program pelayanan publik sesuai dengan kebutuhan dan aspirasi masyarakat. Semakin banyak kebutuhan dan keinginan masyarakat yang diprogramkan dan dijalankan oleh organisasi publik maka kinerja organisasi tersebut dinilai semakin baik.

\section{Responsibilitas}

Responsibilitas di sini menjelaskan apakah pelaksanaan kegiatan organisasi 
publik itu dilakukan sesuai dengan prinsip-prinsip administrasi yang benar atau sesuai dengan kebijaksanaan organisasi baik yang implisit atau eksplisit. Semakin kejelasan organisasi publik itu dilaksanakan sesuai dengan prinsip-prinsip administrasi dan peraturan dan kebijaksanaan organisasi, maka kinerjanya dinilai semakin baik.

3. Akuntabilitas

Akuntabilitas publik menunjuk pada seberapa besar kebijakan dan kegiatan organisasi publik tunduk pada para pejabat politik yang dipilih oleh rakyat (elected officials). Asumsinya di sini adalah bahwa para pejabat politik tersebut, karena dipilih oleh rakyat, dengan sendirinya akan selalu merepresentasikan kepentingan rakyat. Dalam konteks ini kinerja organisasi publik dinilai baik apabila seluruhnya atau setidaknya sebagian besar kegiatannya didasarkan pada upayaupaya untuk memenuhi harapan dan keinginan para wakil-wakil rakyat. Semakin banyak tindak lanjut organisasi atas harapan dan aspirasi pejabat politik, maka kinerja organisasi tersebut itu dinilai makin baik.

Konteks penelitian ini maka konsep yang akan digunakan untuk mengukur kinerja organisasi adalah konsep yang sesuai dengan tugas pokok dan fungsi Pemerintah Desa Cibunut dan berdasarkan data empiris di lapangan (actionable causes), yaitu responsivitas, responsibilitas dan akuntabilitas, sebagaimana pendapat Lenvine dalam Dwiyanto.

\section{HASIL PENELITIAN DAN PEMBAHASAN}

\section{RESPONSIVITAS}

Responsivitas menurut Levine dalam Dwiyanto, (2008: 51) adalah kemampuan organisasi untuk mengenali kebutuhan masyarakat, menyusun agenda dan prioritas pelayanan, dan mengembangkan programprogram pelayanan publik sesuai dengan kebutuhan dan aspirasi masyarakat. Semakin banyak kebutuhan dan keinginan masyarakat yang diprogramkan dan dijalankan oleh organisasi publik maka kinerja organisasi tersebut dinilai semakin baik. Oleh sebab itu peneliti menguraikan responsivitas itu dalam dua indikator berikut.

\section{Daya Tangkap}

Kemampuan daya tanggap dipengaruhi oleh cepat tidaknya Pemerintah Desa Cibunut dalam pengelolaan alokasi dana desa. Kinerja Pemerintah Desa Cibunut dapat dilihat dari responsivitas Pemerintah Desa Cibunut sebagai pengelolaan anggaran alokasi dana desa, sikap cepat tanggap yang dimiliki oleh pemerintah desa Cibunut senantiasa dipelihara sehingga pengelolaan alokasi dana desa dapat diberikan dengan efektif dan efisien. Responsivitas sangat diperlukan dalam pengelolaan alokasi dana desa karena hal tersebut merupakan bukti kemampuan organisasi untuk mengenali kebutuhan masyarakat, menyusun agenda dan prioritas penggunaan anggaran serta mengembangkan program-program sesuai dengan kebutuhan dan aspirasi masyarakat. Daya tangkap dalam pengelolaan alokasi dana desa di Desa Cibunut Kecamatan Argapura Kabupaten Majalengka dilaksanakan oleh Tim Pelaksana ADD Desa Cibunut dapat dikatakan cukup baik, namun kurang direspons oleh Pemerintah Kabupaten terkait dengan pembagian besaran dan waktu penyalurannya Alokasi Dana Desa.

$>$ Keinginan Masyarakat

Masyarakat merupakan salah unsur yang mendukung pengelolaan alokasi dana desa. Wujud dukung masyarakat dapat berupa partisipasi ataupun keikutsertaan mereka dalam tahap perencanaan, pelaksanaan, pemanfaatan 
maupun pemeliharaan. Partisipasi masyarakat sangat diharapkan guna tercapainya tujuan pengelolaan alokasi Dana Desa. Berdasarkan hasil penelitian, masyarakat yang ada di Desa Cibunut sebagian besar mendukung pengelolaan alokasi dana desa. Hal tersebut dapat lihat dari partisipasi masyarakat dalam kegiatan alokasi dana desa seperti kegiatan gotong royong, kegiatan PKK, kegiatan sosial kemasyarakatan ataupun kegiatan karang taruna. Keinginan masyarakat dalam pengelolaan alokasi dana desa di Desa Cibunut Kecamatan Argapura Kabupaten Majalengka dilibatkan partisipasi masyarakat dalam kegiatan yang dianggarkan dari Alokasi Dana Desa.

\section{RESPONSIBILITAS}

Responsibilitas menurut Levine dalam Dwiyanto, (2008: 51) adalah menjelaskan apakah pelaksanaan kegiatan organisasi publik itu dilakukan sesuai dengan prinsipprinsip administrasi yang benar atau sesuai dengan kebijaksanaan organisasi baik yang implisit atau eksplisit. Semakin kejelasan organisasi publik itu dilaksanakan sesuai dengan prinsip-prinsip administrasi dan peraturan dan kebijaksanaan organisasi, maka kinerjanya dinilai semakin baik. Oleh sebab itu peneliti menguraikan responsibilitas itu dalam dua indikator berikut.

\section{$>$ Tanggung Jawab}

Dalam menjalankan suatu program harus didukung dengan adanya tanggung jawab yang berkompeten dan memiliki kemampuan yang baik demi keberhasilan program. Tanggung jawab dalam pengelolaan alokasi dana desa di Desa Cibunut Kecamatan Argapura Kabupaten Majalengka sudah tersusunnya susunan yang terlibat dalam pengelolaan alokasi dana desa meliputi Tim Pelaksana Alokasi Dana
Desa, tim kecamatan Argapura dan Tim Evaluasi dan Monitoring Pelaksanaan APBDes Kabupaten Majalengka.

$>$ Kerja sama

Guna memperlancar jalannya pelaksanaan suatu pengelolaan keuangan yang baik perlu adanya kerja sama dan perhitungan kekuatan atau kekuasaan, kepentingan serta serta strategi yang digunakan oleh para aktor yang terlibat. Bila mana hal ini tidak diperhitungkan dengan matang sangat kemungkinan program yang hendak dilaksanakan tidak sesuai dengan yang diharapkan.

Dalam rangka pengelolaan alokasi dana desa di Kabupaten Majalengka, Pemerintah Daerah mengeluarkan Peraturan Bupati Majalengka Nomor 4 Tahun 2013 tentang Pedoman Pelaksanaan Alokasi Dana Desa Kabupaten Majalengka. Di mana di sana dijelaskan aktor yang terlibat dari tingkat desa sampai dengan tingkat kabupaten. Karena lingkup penelitian ini merupakan pengelolaan Alokasi Dana Desa di Desa Cibunut Kecamatan Argapura, tentunya tim pelaksana tingkat desa merupakan aktor yang memiliki peran strategis dalam pelaksanaan tersebut. Kerjasama dalam pengelolaan alokasi dana desa di Desa Cibunut Kecamatan Argapura Kabupaten Majalengka melakukan pemberdayaan kelembagaan yang ada di masyarakat Desa Cibunut.

\section{Akuntabilitas}

Akuntabilitas publik menurut Levine dalam Dwiyanto, (2008: 51) adalah menunjuk pada seberapa besar kebijakan dan kegiatan organisasi publik tunduk pada para pejabat politik yang dipilih oleh rakyat (elected officials). Asumsinya di sini adalah bahwa para pejabat politik tersebut, karena dipilih oleh rakyat, dengan sendirinya akan selalu merepresentasikan kepentingan rakyat. Dalam konteks ini kinerja organisasi 
publik dinilai baik apabila seluruhnya atau setidaknya sebagian besar kegiatannya didasarkan pada upaya-upaya untuk memenuhi harapan dan keinginan para wakil-wakil rakyat. Semakin banyak tindak lanjut organisasi atas harapan dan aspirasi pejabat politik, maka kinerja organisasi tersebut itu dinilai makin baik. Oleh sebab itu peneliti menguraikan responsibilitas itu dalam dua indikator berikut.

\section{$>$ Tingkat Kesesuaian}

Pengambilan keputusan dalam suatu kebijakan memegang peranan penting dalam pelaksanaan suatu kebijakan, maka pada bagian ini dijelaskan di mana letak pengambilan keputusan dari suatu pengelolaan keuangan yang akan dilaksanakan. Terkait dengan pengelolaan alokasi dana desa di Kabupaten Majalengka, diatur dengan Peraturan Bupati Majalengka Nomor 4 Tahun 2013 tentang Pedoman Pelaksanaan Alokasi Dana Desa Kabupaten Majalengka. Tingkat kesesuaian dalam pengelolaan alokasi dana desa di Desa Cibunut Kecamatan Argapura Kabupaten Majalengka terkait pembagian jumlah besaran ADD perlu dibenahi kembali dan harapannya dapat berpedoman sepenuhnya kepada Peraturan Menteri Dalam Negeri Nomor 37 Tahun 2007 yang menggunakan asas merata dan asas proporsional, sehingga dalam pelaksanaannya tidak terjadi lagi kecemburuan sosial dan sesuai dengan kebutuhan riil masyarakat.

\section{> Tindakan}

Suatu pengelolaan anggaran dalam pelaksanaannya akan melibatkan banyak kepentingan. Kepentingankepentingan yang terlibat dengan pengelolaan alokasi dana desa dapat dilihat pada tujuan tersebut. Tindakan pengelolaan alokasi dana desa di Desa Cibunut dibatasi oleh kepentingan yang dipengaruhi oleh masyarakat dan tim pelaksana ADD Desa Cibunut karena berdasarkan bunyi dari pasal 22 Peraturan Menteri Dalam Negeri Nomor 37 Tahun 2007 menyebutkan bahwa, "penggunaan anggaran alokasi dana desa adalah sebesar 30\% untuk belanja aparatur dan operasional pemerintah desa, sebesar $70 \%$ untuk biaya pemberdayaan masyarakat".

\section{FAKTOR PENDUKUNG DAN FAKTOR} Penghambat Kinerja Pemerintah Desa

\section{Faktor Pendukung}

a) Adanya Peraturan Bupati Majalengka Nomor 4 Tahun 2013 tentang Pedoman Pelaksanaan Alokasi Dana Desa Kabupaten Majalengka

b) Adanya Tim Pelaksana ADD Desa Cibunut dan Tim Evaluasi dan Monitoring Pelaksanaan Anggaran Pendapatan dan Belanja Desa (APBDes) Kabupaten Majalengka.

c) Kelengkapan sarana/prasarana desa dan dalam menjalankan tugas Pemerintah Desa di bantu oleh BPD serta unsur kelembagaan masyarakat seperti LPM, Tim Penggerak PKK, Karang Taruna dan lembaga masyarakat lainnya.

d) Adanya program dari SKPD terkait untuk pembangunan Desa Cibunut serta adanya sumbangan dari pihak ketiga.

e) Partisipasi masyarakat dalam pelaksanaan kebijakan Alokasi Dana Desa baik berupa sumbangan dana, tenaga dan pikiran.

f) Adanya Badan Usaha Milik Desa (BUMDes) yang penyertaan modalnya berasal dari Provinsi.

g) Adanya sumber pendapatan desa selain dari ADD seperti Pendapatan Asli Desa.

\section{Faktor Penghambat}

a) Tingginya angka kemiskinan di Desa Cibunut yang mencapai 45\% dari jumlah Kepala Keluarga yang ada. 
b) Minimnya dana ADD yang diberikan Pemerintah Kabupaten Majalengka dan pembagiannya yang masih disamaratakan untuk seluruh desa.

c) Masih adanya masyarakat yang lebih mementingkan pekerjaannya daripada mengikuti kegiatan gotong royong.

d) Rendahnya pendidikan aparat Desa Cibunut, sehingga pemahaman pelaksana mengenai ADD masih kurang.

e) BPD sebagai wakil masyarakat dan lembaga desa lainnya dalam musrenbang penentuan penggunaan ADD lebih banyak sebagai pendengar sehingga sebagian besar kebijakan ADD ditentukan oleh kepala desa.

f) Waktu pencairan dana ADD cenderung dilaksanakan pada akhir Tahun sehingga menyulitkan pemerintah desa dalam melaksanakan kegiatan dan Penyusunan Anggaran Pendapatan dan Belanja Desa (APBDes).

g) Belum adanya Tim Pendamping Pelaksanaan ADD dari Kecamatan sehingga kurangnya pengawasan yang dilakukan terhadap desa.

h) Kondisi geografis Desa Cibunut yang didominasi oleh lahan pertanian sehingga memerlukan biaya yang besar dalam hal pembangunan fisik.

i) Kurangnya sosialisasi dari Tim Evaluasi dan Monitoring Anggaran Pendapatan dan Belanja Desa (APBDes) Kabupaten Majalengka terkait kebijakan Alokasi Dana Desa.

j) Belum adanya pelatihan untuk bendaharawan desa terkait pengelolaan keuangan desa.

Strategi yang tepat pemerintah desa dalam Pengelolaan Alokasi Dana Desa di Desa Cibunut Kecamatan Argapura Kabupaten Majalengka Provinsi Jawa Barat

1. Mengubah Peraturan Bupati Majalengka Nomor 4 Tahun 2013 tentang Pedoman
Pelaksanaan Alokasi Dana Desa Kabupaten Majalengka.

2. Meningkatkan komunikasi dan koordinasi antar- SKPD terkait dengan pengelolaan Alokasi Dana Desa.

3. Meningkatkan sosialisasi terkait pengelolaan alokasi dana desa.

4. Memaksimalkan penggunaan sumber daya yang tersedia dalam pengelolaan Alokasi Dana Desa baik secara materi ataupun non materi.

5. Melakukan Pembinaan dan Pengawasan terhadap Tim Pelaksana ADD tingkat Desa.

6. Memaksimalkan peran serta lembaga kemasyarakatan desa dalam pengelolaan alokasi dana desa.

7. Mengadakan pelatihan pengelolaan keuangan desa untuk bendaharawan desa.

\section{SIMPULAN DAN SARAN}

\section{SIMPULAN}

1. Kinerja Pemerintah Desa dalam Pengelolaan Alokasi Dana Desa di Desa Cibunut Kecamatan Argapura Kabupaten Majalengka Provinsi Jawa Barat belum efektif dilaksanakan. Hal ini dapat dilihat dari jumlah kepala keluarga miskin di Cibunut semakin meningkat padahal dana yang dikucurkan Pemerintah Kabupaten Majalengka cenderung meningkat. Hal ini dikarenakan hasil pengelolaan Alokasi Dana Desa tidak sepenuhnya dinikmati oleh masyarakat miskin dan pembagian besaran alokasi dana desa yang masih disamaratakan untuk seluruh desa di Kabupaten Majalengka.

2. Faktor-faktor yang mendukung dan menghambat Kinerja Pemerintah Desa dalam Pengelolaan Alokasi Dana Desa di Desa Cibunut Kecamatan Argapura Kabupaten Majalengka Provinsi Jawa Barat yaitu sebagai berikut. 
a. Faktor Pendukung antara lain: Adanya Peraturan Peraturan Bupati Majalengka Nomor 4 Tahun 2013 tentang Pedoman Pelaksanaan Alokasi Dana Desa Kabupaten Majalengka, Adanya Tim Pelaksana ADD Desa Cibunut dan Tim Evaluasi dan Monitoring Pelaksanaan Anggaran Pendapatan dan Belanja Desa (APBDes) Kabupaten Majalengka, Kelengkapan sarana/prasarana desa dan dalam menjalankan tugas Pemerintah Desa di bantu oleh BPD serta unsur kelembagaan masyarakat seperti LPM, Tim Penggerak PKK, Karang Taruna dan lembaga masyarakat lainnya, Adanya program dari SKPD terkait untuk pembangunan Desa Cibunut serta adanya sumbangan dari pihak ketiga, Partisipasi masyarakat dalam pelaksanaan kebijakan Alokasi Dana Desa baik berupa sumbangan dana, tenaga dan pikiran, Adanya Badan Usaha Milik Desa (BUMDes) yang penyertaan modalnya berasal dari Provinsi, Adanya sumber pendapatan desa selain dari ADD seperti Pendapatan Asli Desa.

b. Faktor-faktor Penghambat antara lain: Tingginya angka kemiskinan di Desa Cibunut yang mencapai 45\% dari jumlah Kepala Keluarga yang ada, Minimnya dana ADD yang diberikan Pemerintah Kabupaten Majalengka dan pembagiannya yang masih disamaratakan untuk seluruh desa, Masih adanya masyarakatyang lebih mementingkan pekerjaannya daripada mengikuti kegiatan gotong royong, Rendahnya pendidikan aparat Desa Cibunut, sehingga pemahaman pelaksana mengenai ADD masih kurang, BPD sebagai wakil masyarakat dan lembaga desa lainnya dalam musrenbang penentuan penggunaan ADD lebih banyak sebagai pendengar sehingga sebagian besar kebijakan ADD ditentukan oleh kepala desa, Waktu pencairan dana ADD cenderung dilaksanakan pada akhir Tahun sehingga menyulitkan pemerintah desa dalam melaksanakan kegiatan dan Penyusunan Anggaran Pendapatan dan Belanja Desa (APBDes). Belum adanya Tim Pendamping Pelaksanaan ADD dari Kecamatan sehingga kurangnya pengawasan yang dilakukan terhadap desa. Kondisi geografis Desa Cibunut yang didominasi oleh lahan pertanian sehingga memerlukan biaya yang besar dalam hal pembangunan fisik. Kurangnya sosialisasi dari Tim Evaluasi dan Monitoring Anggaran Pendapatan dan Belanja Desa (APBDes) Kabupaten Majalengka terkait kebijakan Alokasi Dana Desa, Belum adanya pelatihan untuk bendaharawan desa terkait pengelolaan keuangan desa.

3. Strategi yang tepat pemerintah desa dalam Pengelolaan Alokasi Dana Desa di Desa Cibunut Kecamatan Argapura Kabupaten Majalengka Provinsi Jawa Barat. yaitu:

1) Mengubah Peraturan Bupati Majalengka Nomor 4 Tahun 2013 tentang Pedoman Pelaksanaan Alokasi Dana Desa Kabupaten Majalengka.

2) Meningkatkan komunikasi dan koordinasi antar- SKPD terkait dengan pengelolaan Alokasi Dana Desa.

3) Meningkatkan sosialisasi terkait pengelolaan alokasi dana desa.

4) Memaksimalkan penggunaan sumber daya yang tersedia dalam pengelolaan Alokasi Dana Desa baik secara materi ataupun non materi. 
5) Melakukan Pembinaan dan Pengawasan terhadap Tim Pelaksana ADD tingkat Desa.

6) Memaksimalkan peran serta lembaga kemasyarakatan desa dalam pengelolaan alokasi dana desa.

7) Mengadakan pelatihan pengelolaan keuangan desa untuk bendaharawan desa.

\section{SARAN}

1. Teoretis

Perlu dikaji secara mendalam mengenai kinerja pemerintah desa dalam pengelolaan Alokasi Dana Desa.

2. Praktis

1) Pengelolaan Alokasi Dana Desa dapat berjalan secara efektif apabila Pemerintah Daerah Kabupaten Majalengka sesegera mungkin mengubah Peraturan Bupati Majalengka Nomor 4 Tahun 2013 tentang Pedoman Pelaksanaan Alokasi Dana Desa Kabupaten Majalengka. Adapun substansi yang direkomendasikan untuk diubah yaitu: (1) Pembagian besaran alokasi dana desa, disarankan berpedoman sepenuhnya kepada Peraturan Menteri Dalam Negeri Nomor 37 Tahun 2007 yaitu menggunakan asas merata dan asas proporsional (adil) sehingga jumlah dana ADD yang diterima tiap desa besarannya tidak sama karena disesuaikan dengan tingkat kemiskinan, pendidikan dasar, kesehatan, keterjangkauan desa, jumlah penduduk, luas wilayah dan potensi ekonomi. (2) Pembentukan tim pendamping alokasi dana desa tingkat kecamatan karena fungsinya yang sangat penting dalam hal pengendalian dan pengawasan
2) Pemerintah Desa Cibunut sebaiknya perlu memaksimalkan faktor-faktor pendukung dengan terus menggali sumber daya ataupun potensi yang ada dan meminimalisir dampakdampak yang ditimbulkan oleh faktor-faktor penghambat dengan lebih memprioritaskan program kegiatan yang disesuaikan dengan kebutuhan riil dan kepentingan masyarakat melalui perencanaan pembangunan yang bersifat bottom up.

3) Pemerintah Desa Cibunut sebaiknya melaksanakan berbagai alternatif strategi dalam pengelolaan Alokasi Dana Desa dengan saling berkoordinasi antar- organisasi pengelola dan lintas sektor lainnya.

\section{DAFTAR PUSTAKA}

Alsa, Asmadi, 2004. Pendekatan Kualitatif dan Kuantitatif serta Kombinasinya dalam penelitian Psikologi, Yogjakarta.

Dwiyanto, Agus. 2008. Reformasi Birokrasi Publik di Indonesia. Gadjah Mada University Press, Yogyakarta.

Effendi, Khasan 2010. Sosiologi Pemerintahan, Indra Prahasta, Bandung.

Creswell, W Jhon. 2010. Research Design Pendekatan Kualitatif, Kuantitatif, dan Mixed. Pustaka Pelajar.Yogyakarta.

Irahawan Soehartono, 2011. Metode Penelitian Sosial Suatu Teknik Penelitian

Bidang KesejahteraanSosialdanIlmuSosial Lainnya, Rosdakarya, Bandung.

Keban, Yeremias. T. 2004. Enam Dimensi Strategis Administrasi Publik, Konsep, Teori, dan Isu. Gava Media, Yogyakarta.

Mahsun, Mohamad, 2006. Pengukuran kinerja Sektor Publik, Edisi Pertama, BPFE, Yogyakarta.

Moeheriono. 2012. Pengukuran Kinerja Berbasis Kompetensi. Raja Grafindo Persada. Jakarta. 
Moleong, Lexy J. 2002 Metodologi Penelitian Kualitatif. Bandung: PT Remaja Rosdakarya. Bandung.

Naldjoeni, 1998. Geografi Kota dan Desa (Edisi Revisi),PT. Alumni, Bandung.

Nurcholis Hanif, 2005. Teori dan Praktik Pemerintahan dan Otonomi Daerah, PT Grasindo, Jakarta.

Silalahi, Ulber. 2010. Metode Penelitian Sosial. Refika Aditama. Bandung.

Steers, M Richard, 2003. Efektivitas Organisasi Perusahaan, Erlangga, Jakarta,.

Sugiyono. 2005. Memahami Penelitian Kualitatif. Bandung: CV.Alfabeta. Bandung.

2010.Metode Penelitian Kuantitatif Kualitatif dan R\&D. Bandung: CV.Alfabeta. Bandung.

Suharsimi Arikunto, 2006. Prosedur Penelitian. Rineka Cipta, Jakarta.

Robbins dan Judge, 2015. Perilaku Organisasi (Organizational Behavior) Salemba Empat, Jakarta.

Simangungsong, Fernandes, 2014. Transformasi Organisasi: Perubahan Status Desa Menjadi Kelurahan, Alfabeta, Bandung.

Soemantri, Bambang. 2010. Pedoman Penyelenggaraan Pemerintahan Desa. Fokusmedia, Jatinangor.

Soaterdjo Kartohadikusumo, 1984. Desa, Balai Pustaka, Jakarta.
Suyadi Prawirosentono, 1999. Kebijakan Kinerja Karyawan, BPFE, Yogyakarta.

Tangkilisan, Hessel Nogi S. 2005. Evaluasi Kebijakan Publik. Gramedia Widia Sarana Indonesia, Jakarta.

Terry, R George dan Leslie W.Rue. 2010. DasarDasar Manajemen. Bumi Aksara,Jakarta.

Wasistiono Sadu, Tahir Irwan. 2007. Prospek Pengembangan Desa. Fokusmedia. Bandung.

\section{Peraturan Perundang-Undangan}

Undang-Undang No. 23 Tahun 2014 tentang Pemerintahan Daerah.

Undang-Undang No 6 Tahun 2014 tentang Desa.

Peraturan Pemerintah Republik Indonesia Nomor 43 Tahun 2014 tentang Desa.

Peraturan Menteri Dalam Negeri Nomor 37 Tahun 2007 tentang Pedoman Pengelolaan Keuangan Desa.

Peraturan Menteri Dalam Negeri No. 113 Tahun 2014 tentang Pengelolaan Keuangan Desa Peraturan Menteri Desa

Peraturan Daerah Kabupaten Majalengka Nomor 1 Tahun 2015 tentang Desa

Peraturan Bupati Majalengka Nomor 4 Tahun 2013 tentang Pedoman Pelaksanaan Alokasi Dana Desa Kabupaten Majalengka.

Dokumen Rencana Pembangunan Jangka Menengah Desa Cibunut Tahun 20162022. 